\title{
Research on the Relationship between Abnormal Audit Fees of Listed Companies and the Risk of Stock Price Crash
}

\author{
Wanchen $\mathrm{Zhao}^{1, \mathrm{a}}$ \\ ${ }^{1}$ International Business School of Shaanxi Normal University, Xi'an, China
}

\begin{abstract}
The large-scale stock price fluctuations that occur from time to time in the global stock market highlight the important research significance of stock price crash risk. Existing researches have paid little attention to the impact of abnormal audit fees on stock price crash risk. This article explores its relationship with stock prices from this perspective. The relationship between the crash risk and whether the abnormal audit fee can be used as an early warning signal for the company's stock price crash risk has enriched the related research on the influencing factors of the stock price crash risk and the early warning mechanism.
\end{abstract}

\section{Introduction}

Economic globalization has enabled the securities market to develop rapidly, but with it comes the stock price crash caused by the significant increase in the frequency of stock price fluctuations, the orderly operation of investors' personal wealth, the efficiency of social resource allocation, and even the entire capital market, which have a huge impact. In recent years, the global financial crisis of 2008, the plunge of China's A-share market in 2015, and the plunge of China's A-shares affected by equity pledge risk in 2017 all reflected the strong impact of the stock market crash risk on the capital market. Existing research shows that opaque company information caused by management hiding unfavorable information is an important reason for the stock price $\operatorname{crash}^{[1]}$, and the quality of corporate accounting information that occurred during the stock price crash is low, and the transparency of financial reports is poor . Auditors, as "gatekeepers" of capital market information, reduce the information asymmetry between the company and external stakeholders by providing highquality audit services and maintain the orderly operation of the capital market. As an independent third party, the auditor is responsible for the quality of the company's financial report by issuing an audit opinion report. There is a close connection between high-quality audit services and audit fees. Reasonable audit fees are to make up for the costs. On the basis of the audit cost, a part of the audit risk premium is increased. If the audit fee deviates from the normal value to a greater extent, it may represent a greater risk premium faced by the enterprise, which reflects the stock price collapse risk from the side. This article attempts to test whether it can be used as an early warning signal of the company's stock price collapse risk from the perspective of abnormal audit fees.

\section{Theoretical analysis and research hypothesis}

\subsection{Audit fees and stock price collapse risk}

Jin and Myers ${ }^{[2]}$ put forward the "information hiding hypothesis" for individual stock price collapse risk based on the principal-agent theory and the information asymmetry theory, namely management As a result of information asymmetry between management and external investors, the management is in a favorable position in the principal-agent relationship, so it has the motivation and ability to hide the news that is unfavorable to itself to protect its own interests. When the adverse news accumulates to a certain extent, the company cannot When it is accepted, the concentrated release into the market leads to the risk of stock price collapse. The financial report issued by the company is the main way to improve market information disclosure and alleviate the information asymmetry between the entrusted agent and the agent. As an independent third party, the auditor provides highquality audit services to ensure the authenticity and fairness of the audited unit's financial report, which helps The external investors of the enterprise can more fully and truly understand the production and operation status of the enterprise, alleviate the information asymmetry between the principal and the agent, and thus reduce the risk of the company's stock price crash. A reasonable audit fee consists of two parts, one is to make up for the audit cost, and the other is the premium of the audit risk. It is generally believed that the level of audit fees represents the quality of audits. In order to improve the audit quality, accounting firms are usually required to provide more auditors, increase audit time and other methods to strengthen the audit process, and disclose the company's violations to the regulatory department when necessary, thereby improving 
the company's information transparency, reducing audit risks and reducing audit risks. Risk of stock price crash. Auditors tend to charge higher audit fees to audited units in order to make up for the cost of audit risk allocation.

Therefore, Hypothesis 1: The higher the audit fees charged by the auditor, the lower the risk of the company's stock price crash.

\subsection{Abnormal audit fees and stock price crash risks}

Abnormal audit fees usually represent the degree of deviation of audit fees from normal levels of audit fees. The greater the deviation value of abnormal audit fees, the greater the risk the auditor may face. The primary responsibility of the auditor is to reduce errors in the financial statements. When there are many errors, the auditor will reduce the audit risk by making excessive efforts. If the auditor finds that the audited unit has major defects in its internal control, the accounting firm will adopt more substantive procedures and invest more human and time resources to force the management to improve the company's internal earnings management to prevent the accountant from crashing due to the stock price crash. Firms face high litigation risk, reputation risk and regulatory risk. The audit fee is usually set in advance between the beginning of the audit activity, and this price is regarded as a normal audit fee. If the auditors make excessive efforts, they will tend to demand higher audit fees from the audited unit to make up for the audit costs and maintain a certain profit margin. At this time, the auditors guarantee the quality of the audit by charging audit fees that are abnormally higher than normal, thereby reducing the risk of stock price collapse. If the relationship between the two parties is broken due to disagreement during the audit process, the company maliciously reduces the actual audit fee paid to the accounting firm compared to the scheduled audit fee. The auditor may also adopt a more true and fair audit opinion on its financial report. The way of reporting is to fight back. At this time, the auditors improved the audit quality by charging abnormal audit fees below the normal value, thereby reducing the risk of stock price collapse.

Therefore, hypothesis 2: the greater the absolute value of abnormal audit fees, the lower the risk of the company's stock price crash.

\section{Research design}

\subsection{Sample design and data sources}

This article selects the data of China's Shanghai and Shenzhen A-share listed companies from 2002 to 2017 as the research sample. The data comes from the CSMAR and Wind databases, and the initial data obtained are screened as follows: (1) Exclude data of financial companies; (2) Exclude data of ST and ST* listed companies; (3) Exclude samples of companies that conducted IPO in that year; (4) Exclude samples of annual stock returns of less than 30 Data; (5) Remove company samples with annual trading days less than 180 days; (6) Remove sample data with missing variables; (7) Use winsorize processing method to perform $1 \%$ tail reduction on continuous variables.

\subsection{Variable definition}

\subsubsection{Stock Price Crash Risk}

Following Chen et al. ${ }^{[3]}$, we used two different proxies for firm-specific crash risk. First, we estimated the following expanded market model:

$R_{i, t}=\alpha_{0}+\alpha_{1} * R_{m, t-2}+\alpha_{2} * R_{m, t-1}+\alpha_{3} * R_{m, t}+\alpha_{4} * R_{m, t+1}+\alpha_{5} * R_{m, t+2}+\varepsilon_{i, t} \quad$ (1)

where $R_{i, t}$ is the return on stock $i$ in week $t$, and $R_{m, t}$ is the return on the Chinese stock market value-weighted market index in week s. The lead and lag terms for the market index return were included to allow for nonsynchronous trading. The firm-specific weekly return $\omega_{i, t}, \omega_{i, t}=\ln \left(1+\varepsilon_{i, t}\right)$ for firm i in week $t, \varepsilon_{i, t}$ was calculated as the natural logarithm of one plus the residual return from Eq.(1).

Our first measure of crash risk was the negative conditional skewness of firm-specific weekly returns over the fiscal year (NCSKEW). NCSKEW was calculated by taking the negative of the third moment of firm-specific weekly returns for each year and normalizing it by the standard deviation of firm-specific weekly returns raised to the third power. Specifically, for each firm i in year $t$, NCSKE was calculated as follows:

$\operatorname{NCSKEW}_{i, t}=-\left[n(n-1)^{\frac{3}{2}} \sum W_{i, t}{ }^{3}\right] /\left[(n-1)(n-2)\left(\sum W_{i, t}{ }^{2}\right)^{3 / 2}\right]$ using the natural logarithm of the ratio of the standard deviation in the "down" weeks to the standard deviation in the "up" weeks (DOVOL):

DUVOL $_{i, t}=\log \left\{\left[\left(n_{u}-1\right) \sum_{D O W N} W_{i, t}{ }^{2}\right] /\left[\left(n_{d}-1\right) \sum_{U P} W_{i, t}{ }^{2}\right]\right\}$

where $n_{u}$ and $n_{d}$ are the number of up and down weeks, respectively, in year t. A higher value of DUVOL indicates a greater risk of stock price crash. As Chen et al. noted, DUVOL does not involve third moments and is therefore unlikely to be influenced by extreme weekly returns.

\subsubsection{Audit Fees}

This article refers to Wan Dongcan ${ }^{[4]}$, and divides the audit fees into normal audit fees and abnormal audit fees. First take the logarithm of the audit cost to get Ln AUDIT FEE, and fit the annual normal audit cost from the variables given below, and then make the difference between the actual audit cost incurred in the year and the estimated normal audit cost to get the difference representing the abnormal audit cost, And use ABNORMAL AUDIT FEE to represent the absolute value of abnormal audit fees. Ln AUDIT FEE $E_{i, j, t+1}=\beta_{0}+\beta_{1} * \operatorname{SIZE}_{i, t}+\beta_{2} * R E C_{i, t}+\beta_{3} * I N V_{i, t}+\beta_{4} * I N T A N A S S E T_{i, t}+$ $\beta_{5}$ CFFO $_{i, t}+\beta_{6} * R O E_{i, t}+\beta_{7} * L E V_{i, t}+\beta_{8} * B T M_{i, t}+\beta_{9} * T O B I N Q_{i, t}+\beta_{10} * G R O W T H_{i, t}+\beta_{11} *$ $E M_{i, t}+\beta_{12} * L A G$ AUOP $i, t+\beta_{13} *$ ISSUE $_{i, t}+\beta_{14} * \operatorname{LAGLOSS}_{i, t}+\beta_{15} * \operatorname{SOE}_{i, t}+\beta_{16} * \operatorname{TOP}_{i, t}+$ $\beta_{17} * B I G 4_{i, t}+\beta_{18} * I N D E P_{i, t}+\beta_{19} * D_{U A L I T Y}+\sum_{n=1}^{N} I N D_{i, t}+\sum_{t=1}^{T} Y E A R_{i, t}+\varepsilon_{i, t}$

\subsection{Model construction}

Based on the above analysis and previous experience ${ }^{[5]}$, this paper constructs the following model for analysis. To test Hypothesis 1, test whether the risk of a company's stock price crash and the audit fees charged by the auditor have a significant negative relationship, and build the 
model (5).

CRASH $_{i, j, t+1}=\beta_{0}+\beta_{1} *$ Ln AUDIT FEE $E_{i, j, t}+\beta_{2} *$ CRASH $_{i, j, t}+\beta_{3} * R E T_{i, t}+\beta_{4}$ SIGMA $_{i, t}+\beta_{5} *$ $V O L_{i, t}+\beta_{6} * \operatorname{SIZE}_{i, t}+\beta_{7} * \operatorname{ROE}_{i, t}+\beta_{8} * \operatorname{LEV}_{i, t}+\beta_{9} * B T M_{i, t}+\beta_{10} * G R O W T H_{i, t}+\beta_{11} * E M_{i, t}+$ $\beta_{12} * \operatorname{CSCORE}_{i, t}+\beta_{13} * \operatorname{LOSS}_{i, t}+\beta_{14} * \operatorname{SOE}_{i, t}+\beta_{15} * B I G 4_{i, t}+\beta_{16} * I N D E P_{i, t}+\beta_{17} * T O P 1_{i, t}+$ $\beta_{18} * H_{B S H A R E} \varepsilon_{i, t}+\sum_{n=1}^{N} I N D_{i, t}+\sum_{t=1}^{T} Y E A R_{i, t}+\varepsilon_{i, t}$

In order to test hypotheses 2 and examine the relationship between the company's stock price crash risk and the absolute value of abnormal audit fees, the model (6) is constructed.

CRASH $_{i, j, t+1}=\beta_{0}+\beta_{1} * A B N O R M A L A U D I T F E E_{i, j, t}+\beta_{2} * \ln A U D I T F E E_{i, t}+\beta_{3} *$

VARIABLES $S_{i, t}+\varepsilon_{i, t}$

Among them, ABNORMAL AUDIT FEE represents the absolute value of the abnormal audit fee incurred by company $\mathrm{i}$ in year $\mathrm{t}$, which is obtained by formula (4); VARIABLES represents the remaining variables involved in formula (5).

Table1. Variable definitions

\begin{tabular}{|c|c|}
\hline Ln AUDIT FEE & $\begin{array}{l}\text { Audit expenses, the natural logarithm of the audit expenses actually incurred by Company } \mathrm{i} \\
\text { in year } \mathrm{t}+1\end{array}$ \\
\hline $\begin{array}{l}\text { ABNORMAL } \\
\text { AUDIT FEE }\end{array}$ & Abnormal audit costs, | actual audit costs - estimated normal audit costs $\mid$ \\
\hline CRASH & $\begin{array}{l}\text { The stock price crash risk is measured by the negative skew return coefficient (NCSKEW) } \\
\text { and the volatility ratio (DUVOL) of stock return rising and falling }\end{array}$ \\
\hline RET & Annual average weekly return \\
\hline SIGMA & The volatility of the average weekly return \\
\hline VOL & The rate of change of turnover \\
\hline CSCORE & Annual robustness index of companies \\
\hline HBSHARE & If the company issues B shares or $\mathrm{H}$ shares at the same time, the value is 1 , otherwise it is 0 \\
\hline SIZE & Assets, the natural log of a company's total assets \\
\hline REC & Accounts receivable ratio, accounts receivable/total assets \\
\hline INV & Inventory ratio, inventory/total assets \\
\hline INTAN ASSET & Intangible assets ratio, intangible assets/total assets \\
\hline CFFO & Operating cash flow ratio, operating cash flow/total assets \\
\hline ROE & Return on equity, net profit/total assets \\
\hline LEV & Asset-liability ratio, total liabilities/total assets \\
\hline BTM & $\begin{array}{l}\text { Book to market ratio, book value of shareholders' equity/market value of the company at the } \\
\text { balance sheet date }\end{array}$ \\
\hline TOBINQ & $\begin{array}{l}\text { Tobin's Q, market value of the company at the balance sheet date/book value of } \\
\text { shareholders' equity }\end{array}$ \\
\hline GROWTH & $\begin{array}{l}\text { Growth rate of company operating income, (operating income of this year - operating } \\
\text { income of last year)/operating income of last year }\end{array}$ \\
\hline EM & $\begin{array}{l}\text { Earnings management level, the sum of the absolute value of accrual earnings management } \\
\text { over three years }\end{array}$ \\
\hline LAG AUOP & Last audit opinion, when issuing standard audit opinion, the value is 1 ; otherwise, it is 0 \\
\hline ISSUE & $\begin{array}{l}\text { Additional rights offering, additional rights offering or rights offering occurs in the current } \\
\text { year and the value is } 1 \text {, otherwise it is } 0\end{array}$ \\
\hline SOE & $\begin{array}{l}\text { The ownership nature of the company, when the actual controller is the country or the } \\
\text { government, the value is } 1 \text {, otherwise it is } 0\end{array}$ \\
\hline TOP1 & Equity concentration, the shareholding ratio of the largest shareholder \\
\hline BIG4 & $\begin{array}{l}\text { The big Four international accounting firms, in the audit of one of the big four international } \\
\text { accounting firms, the value is } 1 \text {, otherwise it is } 0\end{array}$ \\
\hline INDEP & Ratio of independent directors, number of independent directors/number of directors \\
\hline DUALITY & When the chairman and CEO are the same, the value is 1 ; otherwise, it is 0 \\
\hline YEAR & Annual dummy variable, control time effect \\
\hline IND & Industry virtual variable, control industry influence \\
\hline
\end{tabular}

\section{Empirical results and analysis}

\subsection{Descriptive statistics}

Table2. Descriptive statistics

\begin{tabular}{|l|l|l|l|l|l|l|l|l|}
\hline VARIABLE & N & mean & Sd & min & p25 & p50 & p75 & max \\
\hline NCSKEW $_{t+1}$ & 17701 & -0.311 & 0.994 & -3.105 & -0.923 & -0.313 & 0.32 & 2.267 \\
\hline DUVOL $_{t+1}$ & 17701 & -0.234 & 0.795 & -2.222 & -0.756 & -0.259 & 0.271 & 1.864 \\
\hline Ln AUDIT FEE & 17701 & 13.48 & 0.705 & 12.210 & 13.02 & 13.39 & 13.84 & 16.190 \\
\hline NCSKEW & 17701 & -0.325 & 0.987 & -3.096 & -0.935 & -0.325 & 0.306 & 2.213 \\
\hline DUVOL & 17701 & -0.254 & 0.779 & -2.216 & -0.768 & -0.273 & 0.251 & 1.742 \\
\hline MEAN RET WEEK & 17701 & 0.005 & 0.012 & -0.021 & -0.003 & 0.003 & 0.012 & 0.045 \\
\hline STD WEEK & 17701 & 0.053 & 0.021 & 0.020 & 0.038 & 0.049 & 0.063 & 0.124 \\
\hline OTURNOVER & 17701 & 0.002 & 0.338 & -1.499 & -0.166 & 0.011 & 0.185 & 0.908 \\
\hline LN ASSET & 17701 & 21.9 & 1.248 & 19.120 & 21.04 & 21.78 & 22.64 & 25.710 \\
\hline ROE & 17701 & 0.062 & 0.158 & -0.861 & 0.024 & 0.068 & 0.123 & 0.484 \\
\hline LEV & 17701 & 0.496 & 0.213 & 0.062 & 0.343 & 0.499 & 0.642 & 1.230 \\
\hline BTM & 17701 & 1.023 & 0.879 & 0.088 & 0.428 & 0.745 & 1.314 & 4.753 \\
\hline ASSET GROWTH & 17701 & 0.14 & 0.258 & -0.377 & 0.002 & 0.09 & 0.214 & 1.534 \\
\hline ABS DA JONES & 17701 & 0.193 & 0.136 & 0.010 & 0.096 & 0.157 & 0.251 & 0.683 \\
\hline CSCORE & 17701 & 0.082 & 0.254 & -0.746 & -0.006 & 0.021 & 0.086 & 1.107 \\
\hline
\end{tabular}




\begin{tabular}{|l|l|l|l|l|l|l|l|l|}
\hline INDEP & 17701 & 0.363. & 0.051 & 0.250 & 0.333 & 0.333 & 0.375 & 0.571 \\
\hline TOP1 & 17701 & 0.004 & 0.002 & 0.001 & 0.002 & 0.003 & 0.005 & 0.008 \\
\hline
\end{tabular}

It can be seen from Table 2 that the mean values of NSCKEW and DUVOL in period $\mathrm{t}+1$ are -0.311 and 0.234 , and the mean values in period $t$ are -0.325 and 0.254 , respectively, and the standard deviations of NSCKEW and DUVOL in period $\mathrm{t}+1$ are respectively 0.994 and 0.795 , and the standard deviations in period $\mathrm{t}$ are 0.987 and 0.779 , respectively, indicating that the sample companies differ greatly in these two variables. The average logarithm of AUDITFEE is 13.48, and the standard deviation is 0.705 , indicating that there is a large gap in audit costs between different companies.

\subsection{Regression analysis}

\subsubsection{Regression analysis of audit costs and stock price crash risk}

Table3. Regression results of audit costs and stock price crash risk

\begin{tabular}{|c|c|c|c|c|}
\hline & NCSKEW $_{t+1}$ & $\mathrm{~T}$ value & DUVOL $_{t+1}$ & $\begin{array}{c}\mathrm{T} \\
\text { value }\end{array}$ \\
\hline $\begin{array}{l}\text { LN AUDIT } \\
\text { FEE }\end{array}$ & $-0.0482^{* * *}$ & $(-2.62)$ & $-0.0412^{* * *}$ & $(-2.86)$ \\
\hline NCSKEW & $0.0232^{* * *}$ & $(2.67)$ & & \\
\hline DUVOL & & & $0.0246^{* *}$ & $(2.57)$ \\
\hline $\begin{array}{l}\text { MEAN RET } \\
\text { WEEK }\end{array}$ & $5.972^{* * *}$ & (4.67) & $4.207^{* * *}$ & (3.86) \\
\hline STD WEEK & $1.476^{* *}$ & $(2.52)$ & $1.502^{* * *}$ & $(3.24)$ \\
\hline OTURNOVER & -0.0161 & $(-0.52)$ & -0.0101 & $(-0.41)$ \\
\hline LN ASSET & $0.0994^{* * *}$ & $(8.55)$ & $0.0899^{* * *}$ & $(9.63)$ \\
\hline ROE & -0.0594 & $(-0.97)$ & $-0.0868^{*}$ & $(-1.72)$ \\
\hline LEV & $0.122^{* * *}$ & $(2.79)$ & $0.0841^{* *}$ & $(2.42)$ \\
\hline BTM & $-0.194^{* * *}$ & $(-13.75)$ & $-0.161^{* * *}$ & $\begin{array}{c}(- \\
14.58) \\
\end{array}$ \\
\hline $\begin{array}{c}\text { ASSET } \\
\text { GROWTH }\end{array}$ & $0.0618^{* *}$ & $(2.03)$ & 0.00548 & $(0.23)$ \\
\hline $\begin{array}{l}\text { ABS DA } \\
\text { JONES }\end{array}$ & $0.103^{*}$ & (1.77) & 0.0702 & $(1.52)$ \\
\hline CSCORE & $-0.0947^{* *}$ & $(-2.31)$ & $-0.0970^{* * *}$ & $(-2.82)$ \\
\hline LOSS & $0.0747^{* *}$ & $(2.5)$ & 0.0318 & $(1.35)$ \\
\hline SOE & -0.0158 & $(-0.98)$ & -0.000441 & $(-0.03)$ \\
\hline BIG4 & -0.0254 & $(-0.75)$ & $-0.0577^{* *}$ & $(-2.12)$ \\
\hline INDEP & 0.217 & $(1.49)$ & 0.161 & $(1.39)$ \\
\hline TOP1 & $-19.10^{* * *}$ & $(-3.84)$ & $-16.03^{* * *}$ & $(-4.09)$ \\
\hline HBSHARE & $-0.0900^{* * *}$ & $(-2.93)$ & $-0.0449^{*}$ & $(-1.91)$ \\
\hline $\begin{array}{c}\text { YEAR \& } \\
\text { INDUSTRY }\end{array}$ & yes & - & yes & - \\
\hline CONS & $-1.479^{* * *}$ & $(-6.62)$ & $-1.343^{* * *}$ & $(-7.56)$ \\
\hline F value & 34.89 & - & 42.91 & - \\
\hline R squared & 0.0931 & - & 0.1195 & - \\
\hline $\mathrm{N}$ & 17701 & - & 17701 & - \\
\hline
\end{tabular}
respectively.

Table 3 shows the regression results of the audit fees calculated according to the model (5) and the stock price crash risk. The results show that the logarithm of the current audit fees LNAUDITFEE is significantly negatively correlated with the NCSKEW and DUVOL at $\mathrm{t}+1$ period at the level of $1 \%$., Hypothesis 1 is verified. In addition, in terms of control variables, the asset-liability ratio LEV is significantly positively correlated with the stock price crash risk of $t+1$ period, and the book market value ratio is significantly negatively correlated with the stock market crash risk of $\mathrm{t}+1$ period. The proportion of the largest shareholder holding TOP1 is both NCSKEW and DUVOL at period $\mathrm{t}+1$ were significantly negatively correlated at the $1 \%$ level, consistent with previous results.

\subsubsection{Regression analysis of abnormal audit fees and stock price crash risk}

Table4. Regression results of abnormal audit fees and stock price crash risk

\begin{tabular}{|c|c|c|c|c|}
\hline & NCSKEW $_{t+1}$ & T value & DUVOL $_{t+1}$ & T value \\
\hline $\begin{array}{l}\text { ABNORMAL } \\
\text { AUDIT FEE }\end{array}$ & $-0.270^{* * *}$ & $(-2.71)$ & $-0.171^{* *}$ & $(-2.23)$ \\
\hline $\begin{array}{l}\text { LN AUDIT } \\
\text { FEE }\end{array}$ & $0.205^{* *}$ & (2.14) & 0.119 & $(1.62)$ \\
\hline NCSKEW & $0.0234^{* * *}$ & $(2.68)$ & & \\
\hline DUVOL & & & $0.0245^{* *}$ & $(2.56)$ \\
\hline $\begin{array}{l}\text { MEAN RET } \\
\text { WEEK }\end{array}$ & $5.689^{* * *}$ & $(4.42)$ & $4.038^{* * *}$ & (3.69) \\
\hline STD WEEK & $1.383^{* *}$ & $(2.35)$ & $1.425^{* * *}$ & $(3.06)$ \\
\hline OTURNOVER & -0.0122 & $(-0.39)$ & -0.00748 & $(-0.31)$ \\
\hline LN ASSET & -0.000923 & $(-0.02)$ & 0.0263 & $(0.86)$ \\
\hline ROE & $-0.0918^{*}$ & $(-1.69)$ & $-0.0926^{* *}$ & $(-2.09)$ \\
\hline LEV & 0.0558 & $(1.15)$ & 0.0395 & $(1.04)$ \\
\hline BTM & $-0.174^{* * *}$ & $\begin{array}{c}(- \\
11.07)\end{array}$ & $-0.148^{* * *}$ & $\begin{array}{c}(- \\
12.17) \\
\end{array}$ \\
\hline $\begin{array}{c}\text { ASSET } \\
\text { GROWTH }\end{array}$ & $0.0827^{* *}$ & $(2.53)$ & 0.019 & $(0.73)$ \\
\hline $\begin{array}{l}\text { ABS DA } \\
\text { JONES }\end{array}$ & $0.117^{* *}$ & (2) & $0.0773^{*}$ & $(1.66)$ \\
\hline CSCORE & $-0.0992^{* *}$ & $(-2.41)$ & $-0.101^{* * *}$ & $(-2.92)$ \\
\hline ISSUE & -0.0151 & $(-0.62)$ & -0.007 & $(-0.36)$ \\
\hline SOE & -0.00792 & $(-0.49)$ & 0.00398 & $(0.31)$ \\
\hline BIG4 & $-0.206^{* * *}$ & $(-2.78)$ & $-0.172^{* * *}$ & $(-2.98)$ \\
\hline AUOP & $0.0771^{*}$ & (1.93) & 0.0445 & $(1.42)$ \\
\hline INDEP & 0.144 & $(0.98)$ & 0.117 & $(0.99)$ \\
\hline TOP1 & $-14.63^{* * *}$ & $(-2.79)$ & $-13.16^{* * *}$ & $(-3.18)$ \\
\hline DUALITY & 0.0231 & $(1.15)$ & 0.0104 & $(0.66)$ \\
\hline HBSHARE & $-0.0947^{* * *}$ & $(-3.07)$ & $-0.0477^{* *}$ & $(-2.03)$ \\
\hline $\begin{array}{c}\text { YEAR \& } \\
\text { INDUSTRY }\end{array}$ & yes & - & yes & - \\
\hline CONS & $-2.637^{* * *}$ & $(-5.60)$ & $-2.076^{* * *}$ & $(-5.70)$ \\
\hline F value & 33.1 & - & 40.64 & - \\
\hline R squared & 0.0936 & - & 0.1199 & - \\
\hline $\mathrm{N}$ & 17701 & - & 17701 & - \\
\hline
\end{tabular}

Table 4 shows the regression results of abnormal audit fees and stock price crash risk calculated according to model (6). The current abnormal audit fees ABNORMALAUDITFEE are significantly negatively correlated to NCSKEW and DUVOL in period $t+1$. Hypothesis 2 has been verified. In addition, in terms of control variables, the relationship between the book-tomarket ratio $\mathrm{BTM}$, accounting conservatism level CSCORE, the largest shareholder's shareholding ratio TOP1 and the simultaneous issuance of B shares or $\mathrm{H}$ shares HBSHARE and other variables on the stock price collapse risk of $\mathrm{t}+1$ period and the table The results in 3 are consistent. Whether the audited client is audited by one of the four major international (PwC, Deloitte, EY, KPMG) BIG4 is significantly negatively correlated with the NCSKEW and DUVOL of the $t+1$ period at the level of $1 \%$. 


\section{Robustness test}

In order to make the research results more robust, we considered the impact of dividend factors on the relationship between audit fees, abnormal audit fees and stock price crashes, and conducted regression analysis based on models (5) and (6), respectively. The results show that the logarithm of current audit fees, abnormal audit fees and NCSKEW and DUVOL in period $t+1$ all show a significant negative correlation, which further verifies the conclusion of this article. The above research conclusions are limited to space and are not listed.

\section{Conclusion}

This article uses the data of Shanghai and Shenzhen Ashare superior companies from 2002 to 2017 as a research sample, and mainly studies the relationship between the auditor's audit fees, abnormal audit fees and the company's stock price crash risk. The results of the study show that the higher the audit fee charged by the auditor, the lower the risk of the company's stock price crash. As for the abnormal audit fees of the auditors, the research results show that the greater the absolute value of the abnormal audit fees, the lower the risk of the company's stock price crash. The robustness test also verifies that the above empirical results are robust. The research in this paper enriches the research framework of the literature on the influencing factors of the stock price crash risk of the company, and analyzes the internal logic between it and the stock price crash risk from the unique research perspective of abnormal audit fees. The research conclusions also have important policy implications for the supervisory authorities. How to further standardize the auditing behavior of the audit firm and improve the audit quality of the auditors are the matters that the regulatory department should focus on, so that it can play its due role in reducing the degree of information asymmetry between the company and investors, and reduce the company's stock price crash risk, maintain the orderly operation of the securities market and the interests of investors.

\section{References}

1. Fang Junxiong, Chu Jian, Chen Shiting. Stock price crash risk and adjustment of audit opinion type. China Accounting Review, 2016, 14(03) : 317-344.

2. Jin, L., \& Myers, S.C. 2006. R2 around the World New Theory and New Tests. Journal of Financial Economics, 79, 257-292.

3. Chen, J., Hong, H., Stein, J., 2001. Forecasting crashes: trading volume, past returns, andconditional skewness in stock prices. Journal of Financial Economics 61, 345-381.

4. Wan Dongcan. 2015. Audit Fees and stock price crash risk. Audit Research, 06:85 -93.

5. Xu Nianxing, YU Shang-yao, Yi Zhi-hong. 2013. Herd behavior and stock price crash risk of institutional investors. Management World, 07:31-43. 